\title{
Preliminary implications for Europe of the 2011 influenza season in five temperate southern hemisphere countries
}

V Lopez Chavarrias (vicente.lopez@ecdc.europa.eu) ${ }^{1}$, E Broberg ${ }^{1}$, A Nicoll ${ }^{1}$

1. European Centre for Disease Prevention and Control (ECDC), Stockholm, Sweden

Citation style for this article:

Lopez Chavarrias V, Broberg E, Nicoll A. Preliminary implications for Europe of the 2011 influenza season in five temperate southern hemisphere countries. Euro Surveill. 2011;16(50):pii=20044. Available online: http://www.eurosurveillance.org/ViewArticle.aspx?Articleld=20044

Article published on 15 December 2011

The 2011 influenza season (May to October) in the southern hemisphere was dominated by the $A\left(\mathrm{H}_{1} \mathrm{~N}_{1}\right)$ viruses that emerged during the 2009 influenza $A\left(\mathrm{H}_{1} \mathrm{~N}_{1}\right)$ pandemic and influenza $B$ viruses, although the proportion of these two varied between and within countries. Some influenza $\mathrm{A}\left(\mathrm{H}_{3} \mathrm{~N}_{2}\right)$ viruses were also seen. We discuss here the preliminary implications for Europe of the 2011 influenza season in five temperate southern hemisphere countries.

Since 2009, the European Centre for Disease Prevention and Control (ECDC) has been monitoring the patterns of human influenza infection in five temperate southern hemisphere countries in their winters (May to October) as this gives some indication of what can be expected in the following northern hemisphere winter [1-8].

The pattern of influenza in the southern hemisphere is one of the many factors that the Centre takes into consideration in formulating its risk assessment in relation to severity and impact for epidemics of influenza [8].

From May to October 2011, ECDC monitored what was occurring in the five southern hemisphere countries in terms of virology, epidemiology and impact on healthcare of influenza and other respiratory viruses. One important source was the reports that the countries place regularly on the websites of their ministries of health and public health institutes [1-5]. In addition, more specific analyses and reports - especially related to the impact (in the sense of pressures on primary and secondary healthcare services) - as well as information on unusual features were sought from influenza experts in the countries by a simple questionnaire to get information that was not otherwise available. The aim of the questionnaires was to gather details on the impact on the healthcare service, risk factors associated with severe cases, observed complicating conditions, vaccine coverage among the general population and anything unusual that could have been observed. Three reference time-points were indicated for comparisons: before the 2009 influenza $A\left(\mathrm{H}_{1} \mathrm{~N}_{1}\right)$ pandemic, during the pandemic, and the first post-pandemic winter season (2010).

\section{Findings and their implications for Europe}

The findings for the five countries are shown in the Table, combining information from the questionnaire, the national websites and an earlier summary of the epidemiology and virology from the World Health Organization [9].

The observed respiratory virus pattern was mixed although no pre-pandemic seasonal influenza $A\left(\mathrm{H}_{1} \mathrm{~N}_{1}\right)$ viruses were seen in the southern hemisphere in the 2011 season. In 2011, in Argentina and Chile, respiratory syncytial virus (RSV) was the most frequent isolate, followed by influenza $\mathrm{A}\left(\mathrm{H}_{1} \mathrm{~N}_{1}\right)$ pdmog virus. South Africa also reported a predominance of RSV during 2011. In Australia, the most frequently isolated strains were influenza $A\left(\mathrm{H}_{1} \mathrm{~N}_{1}\right)$ pdmog and influenza $B$ viruses. New Zealand observed a pattern of influenza $B$ viruses (Victoria lineage) dominating in 2011. This has been seen at intervals, approximately once every three seasons. All countries reported some influenza $A\left(\mathrm{H}_{3} \mathrm{~N}_{2}\right)$ circulation, although it was not the predominant influenza $A$ subtype in any country.

The match with seasonal vaccines was found to be good overall [10]. Australia reported a regional cluster of oseltamivir-resistant influenza $A\left(\mathrm{H}_{1} \mathrm{~N}_{1}\right)$ viruses which were collected from patients without oseltamivir exposure (only one of the 29 cases infected with the resistant virus had received oseltamivir treatment). The individuals were not known to be immunosuppressed [11-13]. The viruses remained sensitive to zanamivir but were resistant to adamantanes. All the resistant influenza $A\left(\mathrm{H}_{1} \mathrm{~N}_{1}\right)$ viruses were found to carry a point mutation in their neuraminidase genes which encoded a histidine to tyrosine substitution at residue $275(\mathrm{H} 275 \mathrm{Y})$ of the neuraminidase active site.

Argentina reported higher burden on the healthcare system in 2011 than during the 2010 season and Chile noted higher pressure than usual on child healthcare 


\begin{tabular}{|c|c|c|c|c|c|}
\hline $\begin{array}{l}\text { Information } \\
\text { requested in the } \\
\text { questionnaire }\end{array}$ & Argentina & Australia & Chile & New Zealand & South Africa \\
\hline $\begin{array}{l}\text { What was the } \\
\text { observed influenza } \\
\text { viral mix circulating in } \\
\text { your country during } \\
\text { the } 2011 \text { influenza } \\
\text { season? }\end{array}$ & $\begin{array}{l}\mathrm{A}\left(\mathrm{H}_{3} \mathrm{~N}_{2}\right), \mathrm{A}\left(\mathrm{H}_{1} \mathrm{~N}_{1}\right) \\
\text { pdmo9, peak of RSV } \\
\text { in children under } \\
\text { one year of age (from } \\
\text { May to July which } \\
\text { has been observed } \\
\text { before) }\end{array}$ & $\begin{array}{l}\mathrm{A}\left(\mathrm{H}_{1} \mathrm{~N}_{1}\right) 2009, \mathrm{~B}, \\
\text { occasionally } \mathrm{A}\left(\mathrm{H}_{3} \mathrm{~N}_{2}\right), \\
\text { some emerging } \\
\mathrm{A}\left(\mathrm{H}_{1} \mathrm{~N}_{1}\right) \text { pdmog } \\
\text { oseltamivir-resistant } \\
\text { strains }\end{array}$ & $\begin{array}{l}\text { RSV was more } \\
\text { prominent than } \\
\text { usually during } \\
\text { the } 2011 \text { season. } \\
\text { Its detections } \\
\text { surpassed influenza } \\
\text { A isolations, among } \\
\text { which the } \mathrm{A}\left(\mathrm{H}_{1} \mathrm{~N}_{1}\right) \\
\text { subtype was more } \\
\text { frequently isolated } \\
\text { than the } \mathrm{A}\left(\mathrm{H}_{3} \mathrm{~N}_{2}\right) \text {. }\end{array}$ & $\begin{array}{l}\text { The predominant } \\
\text { strains have been } \\
\text { of the } B / \text { Victoria } \\
\text { subtype/lineage, with } \\
\text { some } A\left(\mathrm{H}_{3} \mathrm{~N}_{2}\right) \text { and } \\
A\left(\mathrm{H}_{1} \mathrm{~N}_{1}\right) \text {. }\end{array}$ & $\begin{array}{l}\mathrm{A}\left(\mathrm{H}_{1} \mathrm{~N}_{1}\right) \text { predominant } \\
\text { subtype until } \\
\text { August, associated } \\
\text { with the first peak } \\
\text { of influenza-like } \\
\text { illness/severe } \\
\text { acute respiratory } \\
\text { infections; secondary } \\
\text { peak associated } \\
\text { with } \mathrm{A}\left(\mathrm{H}_{3} \mathrm{~N}_{2}\right) \text { and B } \\
\text { viruses. }\end{array}$ \\
\hline $\begin{array}{l}\text { Are the primary care } \\
\text { services in your } \\
\text { country subject to } \\
\text { unusual pressures of } \\
\text { any kind? }\end{array}$ & $\begin{array}{l}\text { More than during the } \\
2010 \text { season but less } \\
\text { than during the } 2009 \\
\text { pandemic }\end{array}$ & $\begin{array}{l}\text { No special burden } \\
\text { during the } 2011 \\
\text { season }\end{array}$ & $\begin{array}{l}\text { High pressure during } \\
2011 \text { due to the early } \\
\text { presence of RSV } \\
\text { viruses, mostly in } \\
\text { children }\end{array}$ & $\begin{array}{l}\text { Less pressures } \\
\text { observed than during } \\
\text { the } 2010 \text { season and } \\
\text { much less than during } \\
\text { the } 2009 \text { pandemic }\end{array}$ & $\begin{array}{l}\text { Not systematically } \\
\text { measured in South } \\
\text { Africa }\end{array}$ \\
\hline $\begin{array}{l}\text { Are there any } \\
\text { reports of secondary } \\
\text { health centres of } \\
\text { your country being } \\
\text { particularly subject to } \\
\text { pressures of any kind, } \\
\text { compared to previous } \\
\text { seasons? }\end{array}$ & $\begin{array}{l}\text { More than during the } \\
2010 \text { season but less } \\
\text { than during the } 2009 \\
\text { pandemic }\end{array}$ & $\begin{array}{l}\text { Less than during the } \\
2010 \text { season and the } \\
2009 \text { pandemic }\end{array}$ & $\begin{array}{l}\text { More than during the } \\
2010 \text { season but less } \\
\text { than during the } 2009 \\
\text { pandemic; hospital } \\
\text { admissions began } \\
\text { earlier than usual }\end{array}$ & $\begin{array}{l}\text { Less pressures } \\
\text { observed than } \\
\text { during both the } 2010 \\
\text { season and the } 2009 \\
\text { pandemic }\end{array}$ & $\begin{array}{l}\text { Same pressure as } \\
\text { during the } 2010 \\
\text { season but less } \\
\text { pressure than during } \\
\text { the } 2009 \text { pandemic }\end{array}$ \\
\hline $\begin{array}{l}\text { Has there been } \\
\text { marked heterogeneity } \\
\text { (more pressures in } \\
\text { some part(s) of the } \\
\text { country) in primary } \\
\text { and/or secondary } \\
\text { care? }\end{array}$ & $\begin{array}{l}\text { There were higher } \\
\text { pressures in } \\
\text { both primary and } \\
\text { secondary care in the } \\
\text { region of Mendoza }\end{array}$ & $\begin{array}{l}\text { No differences } \\
\text { observed }\end{array}$ & $\begin{array}{l}\text { Higher pressures } \\
\text { observed in the } \\
\text { metropolitan regions }\end{array}$ & $\begin{array}{l}\text { A slight geographic } \\
\text { variation but this is } \\
\text { the norm every winter }\end{array}$ & $\begin{array}{l}\text { No big differences } \\
\text { observed }\end{array}$ \\
\hline $\begin{array}{l}\text { Are the risk groups } \\
\text { (people experiencing } \\
\text { severe disease) the } \\
\text { same this year?c }\end{array}$ & $\begin{array}{l}\text { Healthy people with } \\
\text { severe disease only } \\
\text { observed in during } \\
\text { the pandemic }\end{array}$ & $\begin{array}{l}\text { People with } \\
\text { co-morbidities, as in } \\
\text { previous years }\end{array}$ & $\begin{array}{l}\text { The same groups as } \\
\text { in the } 2009 \text { pandemic } \\
\text { and } 2010 \text { season }\end{array}$ & $\begin{array}{l}\text { The same groups as } \\
\text { in } 2009 \text { and } 2010\end{array}$ & $\begin{array}{l}\text { The same groups as } \\
\text { in the } 2009 \text { pandemic } \\
\text { and } 2010 \text { season }\end{array}$ \\
\hline $\begin{array}{l}\text { Are the age groups } \\
\text { (people experiencing } \\
\text { severe disease) the } \\
\text { same this year?c }\end{array}$ & $\begin{array}{l}\text { The same as in } 2010 \\
\text { and } 2009 \text { when the } \\
\text { influenza } A\left(\mathrm{H}_{1} \mathrm{~N}_{1}\right) \\
\text { pdmog virus was } \\
\text { involved; the same } \\
\text { episodes observed } \\
\text { than in pre-pandemic } \\
\text { times with regards to } \\
\text { the } \mathrm{A}\left(\mathrm{H}_{3} \mathrm{~N}_{2}\right) \text { virus }\end{array}$ & $\begin{array}{l}\text { Slight increase in } \\
\text { the median age } \\
\text { of infection, more } \\
\text { like the expected } \\
\text { seasonal pattern }\end{array}$ & $\begin{array}{l}\text { The same as in the } \\
2009 \text { pandemic but } \\
\text { different compared to } \\
\text { the } 2010 \text { season }\end{array}$ & $\begin{array}{l}\text { Children (0-19 years) } \\
\text { and young adults } \\
\text { (20-34 years) had } \\
\text { a higher disease } \\
\text { burden compared to } \\
\text { other age groups, as } \\
\text { in the } 2009 \text { and } 2010 \\
\text { seasons }\end{array}$ & $\begin{array}{l}\text { Greater proportion } \\
\text { of patients in the } \\
\text { age group of one to } \\
\text { four year-olds and } \\
\text { a lower proportion } \\
\text { in the age group of } \\
25-44 \text { year-olds in } \\
2011 \text { as compared } \\
\text { with } 2010 \text { season; no } \\
\text { information indicated } \\
\text { with regards to pre- } \\
\text { pandemic times }\end{array}$ \\
\hline $\begin{array}{l}\text { Observed } \\
\text { complicating } \\
\text { conditions and other } \\
\text { infections in severe } \\
\text { cases }^{c}\end{array}$ & $\begin{array}{l}\text { Similar to the } 2009 \\
\text { pandemic }\end{array}$ & None observed & $\begin{array}{l}\text { Most of the severe } \\
\text { acute respiratory } \\
\text { infections cases were } \\
\text { affected by influenza } \\
\mathrm{A}\left(\mathrm{H}_{1} \mathrm{~N}_{1}\right) \text { pdmog virus; } \\
\text { some also attributed } \\
\text { to influenza } \mathrm{A}\left(\mathrm{H}_{3} \mathrm{~N}_{2}\right)\end{array}$ & $\begin{array}{l}\text { No relevant features } \\
\text { observed }\end{array}$ & $\begin{array}{l}\text { Not specific issues } \\
\text { noted in relation to } \\
\text { acute respiratory } \\
\text { distress syndrome } \\
\text { or secondary } \\
\text { bacterial infections/ } \\
\text { co-infections }\end{array}$ \\
\hline $\begin{array}{l}\text { Observed seasonal } \\
\text { immunisation } \\
\text { coverage and/ } \\
\text { or acceptance of } \\
\text { vaccination }\end{array}$ & $\begin{array}{l}\text { Higher than during } \\
\text { the } 2010 \text { season and } \\
\text { pre-pandemic times }\end{array}$ & Not reported & $\begin{array}{l}\text { Lower than in the } \\
2010 \text { season and pre- } \\
\text { pandemic times }\end{array}$ & $\begin{array}{l}\text { Slightly lower than } \\
\text { during the } 2010 \\
\text { season and higher } \\
\text { than in pre-pandemic } \\
\text { times }\end{array}$ & $\begin{array}{l}\text { About the same as } \\
\text { during the } 2010 \\
\text { season but higher } \\
\text { than in pre-pandemic } \\
\text { times }\end{array}$ \\
\hline
\end{tabular}

RSV: respiratory syncytial virus.

a None of the preceding seasonal influenza $A\left(\mathrm{H}_{1} \mathrm{~N}_{1}\right)$ viruses was observed in any of the five countries [9].

b As compared with the 2010 season and the 2009 influenza $\left.\mathrm{A}_{(} \mathrm{H}_{1} \mathrm{~N}_{1}\right)$ pandemic.

c As compared with the 2010 season, the 2009 influenza $\mathrm{A}\left(\mathrm{H}_{1} \mathrm{~N}_{1}\right)$ pandemic, and prior to the pandemic.

d As compared with the 2010 season and prior to the 2009 influenza $A\left(\mathrm{H}_{1} \mathrm{~N}_{1}\right)$ pandemic 
services from illness among children, but mostly due to RSV (Chile is one of the few countries in the world outside the European Union that routinely reports on RSV detections). Australia and New Zealand reported less burden on the healthcare system in 2011 than in 2010, and much less than during the 2009 influenza $A\left(\mathrm{H}_{1} \mathrm{~N}_{1}\right)$ pandemic. In hospitals, the only unusual impact was high burden on the secondary healthcare system in Argentina and the burden through childhood RSV in Chile. Some geographical differences were reported in the burden of respiratory illness on the primary healthcare system in Chile and on the secondary healthcare system in Argentina.

Australia reported that surveillance data on severe disease remained consistent with people with co-morbidities being at higher risk of severe disease but that the age groups with severe disease had reverted to the pattern seen in the period before the 2009 pandemic. However, during 2011, three other countries noted a similarity with the pandemic pattern of severe disease in younger people (Table). There were fewer reports of acute respiratory distress syndrome than during the 2009 influenza $A\left(\mathrm{H}_{1} \mathrm{~N}_{1}\right)$ pandemic.

Three of the four countries that reported information on vaccine coverage, Argentina, New Zealand, and South Africa, indicated that vaccine coverage for seasonal influenza among the recommended groups was higher than before the 2009 influenza $A\left(\mathrm{H}_{1} \mathrm{~N}_{1}\right)$ pandemic, whereas Chile reported that coverage was lower than during the 2009 influenza $A\left(\mathrm{H}_{1} \mathrm{~N}_{1}\right)$ pandemic and in 2010 (Table).

\section{Discussion and limitations}

The influenza virological pattern seen in the southern hemisphere in 2011 was not consistent enough to make a clear prediction for the season 2011/12 in Europe. However, it was different from what was seen in 2010/11 in the northern hemisphere for Europe (predominance of influenza $\mathrm{A}\left(\mathrm{H}_{1} \mathrm{~N}_{1}\right)$ pdmog and, to a lesser extent, influenza B viruses), North America and North Asia (predominance of influenza $\mathrm{A}\left(\mathrm{H}_{3} \mathrm{~N}_{2}\right)$ virus).

In relation to the seasons before 2011, the overall impact of influenza in the southern hemisphere was lower in 2010 than in 2009, with some exceptions, e.g. locally in New Zealand $[14,15]$.The reports of circulation of oseltamivir-resistant influenza $A\left(\mathrm{H}_{1} \mathrm{~N}_{1}\right)$ viruses are concerning, although these were also observed during the 2009 influenza $A\left(\mathrm{H}_{1} \mathrm{~N}_{1}\right)$ pandemic and in Europe in $2010 / 11[16,17]$. This indicates a particular need to monitor these viruses in Europe in the 2011/12 season to detect any rise in prevalence as was observed for the pre-2009 influenza $A\left(\mathrm{H}_{1} \mathrm{~N}_{1}\right)$ seasonal viruses in the $2007 / 08$ season [18].

The main limitation of this survey lies in its descriptive character. In addition, the selection of the contributors did not follow a systematic procedure. Data derived from more thorough quantitative and statistical analysis would render the information more meaningful but cannot be generated while there are such differences in the surveillance systems in the countries concerned.

The findings on the impact of influenza in the southern hemisphere in 2011 are reassuring for Europe before the influenza season reaches its peak, usually around January. The differences in the impact of influenza observed within the 2011 season between Australasia, South Africa and the southern cone of South America may become more apparent in future seasons. This was the case in the last inter-pandemic period, when large differences existed between continents for both the southern and the northern hemisphere [19]. This may reduce, but not eliminate, the utility of this kind of surveillance for Europe in the future.

\section{Acknowledgements}

The authors would like to thank a number of colleagues for their assistance in preparing this report: Brett Archer, Jorge Camara, Cheryl Cohen, Rodrigo Fasce Pineda, Sue Huang, Darren Hunt, Heath Kelly, Anne Kelso, Andrea Olea Normandin, Viviana Sotomayor and Osvaldo Cesar Uez. However, the comments in the report are the responsibility of the authors alone.

\section{References}

1. Argentina Ministry of Health. Situacion de enfermedades respiratorias en la Argentina 2011 - Alerta epidemiologico. [Situation of respiratory diseases in Argentina 2011 Epidemiological alerts]. [Accessed 10 Aug 2011]. Spanish. Available from: http://www.msal.gov.ar/gripe2011/index.html

2. Australian Government. Department of Health and Ageing. Influenza. Australian influenza report 2011. [Accessed 10 Aug 2011]. Available from: http://www.health.gov.au/internet/ main/publishing.nsf/Content/cda-surveil-ozflu-flucurr.htm

3. Chile Ministry of Health. Department of epidemiology. Vigilancia Influenza. [Influenza surveillance]. [Accessed 10 Aug 2011]. Spanish. Available from: http://epi.minsal.cl/

4. New Zealand Ministry of Health. Public Health Surveillance (Virology) - Influenza Weekly Updates. [Accessed 12 Aug 2011]. Available from: http://www.moh.govt.nz/moh.nsf/indexmh/ influenza-seasonal-weeklyupdate

5. South Africa National Institute for Communicable Diseases. Influenza surveillance report - South Africa. [Accessed 12 Aug 2011]. Available from: http://www.nicd. ac.za/?page $=$ seasonal_influenza\&id $=72$

6. European Centre for Disease Prevention and Control (ECDC). Risk Assessment. Seasonal influenza 2010-2011 in Europe (EU/ EEA countries). Stockholm: ECDC. 25 Jan 2011. Available from: http://ecdc.europa.eu/en/publications/Publications/110125_ RA_Seasonal_Influenza_EU-EEA_2010-2011.pdf

7. European Centre for Disease Prevention and Control (ECDC). Differing patterns of influenza activity in the southern hemisphere during and between the 2009 pandemic and the 2010 winter influenza season - the usefulness for Europe. Stockholm: ECDC. 4 Apr 2011. Available from: http://ecdc. europa.eu/en/activities/sciadvice/Lists/ECDC\%20Reviews/ ECDC_DispForm.aspx?List $=512 \mathrm{ff}_{74} \mathrm{f} \% 2 \mathrm{D} 77 \mathrm{~d} 4 \% 2 \mathrm{D} 4 \mathrm{ad} 8 \% 2 \mathrm{Db} 6 \mathrm{~d}$ $6 \% 2$ Dbfof 23083 f $30 \&$ ID $=1048$ \& RootFolder $=\% 2$ Fen $\% 2$ Factivitie s\%2Fsciadvice \%2FLists\%2FECDC\%2oReviews

8. Nicoll A. Planning for uncertainty: a European approach to informing responses to the severity of influenza epidemics and pandemics. World Health Organization; Bulletin of the World Health Organization. 2011;89:542-4. doi: 10.2471 BLT.11.089508.

9. World Health Organization (WHO). Review of the 2011 winter influenza season, Southern Hemisphere. Wkly Epidemiol Rec. 2011;86(44):488-96.

10. World Health Organization (WHO). Recommended composition of influenza virus vaccines for use in the 2012 southern 
hemisphere influenza season. WHO. Sept 2011. Available from: http://www.who.int/influenza/vaccines/virus/ recommendations/2011_09_recommendation.pdf

11. European Centre for Disease Prevention and Control (ECDC). Rapid risk assessment: Oseltamivir-resistant influenza $\mathrm{A}\left(\mathrm{H}_{1} \mathrm{~N}_{1}\right) 2009$ cluster in Australia. ECDC. Sept 2011. Available from: http://ecdc.europa.eu/en/publications/ Publications/110906_TER_Rapid_Risk_Assessment_ Oseltamivir-resistant\%2oinfluenza\%2oA.pdf

12. McKimm-Breschkin J, Trivedi T, Hampson A, Hay A, Klimov $A$, Tashiro $M$, et al. Neuraminidase sequence analysis and susceptibilities of influenza virus clinical isolates to zanamivir and oseltamivir. Antimicrob Agents Chemother. 2003;47(7):2264-72.

13. Hurt AC, Hardie K, Wilson NJ, Deng YM, Osbourn M, Gehrig $\mathrm{N}$, et al. Community Transmission of Oseltamivir-Resistant A(H1N1)pdmog Influenza. N Engl J Med. Forthcoming 2012.

14. Van Kerkhove M D, Mounts AW. 2009 versus 2010 comparison of influenza activity in southern hemisphere temperate countries. Influenza Other Respi Viruses.2011;5(6):375-9.

15. Grant K, Franklin L, Kacmarek M, Frankiln L, Hurt A, Kostecki $R$, et al. Continued dominance of pandemic $A\left(\mathrm{H}_{1} \mathrm{~N}_{1}\right) 2009$ influenza in Victoria, Australia in 2010. West Pacific Surv Response 2011; 2(3):1-9. Available from: http://www. wpro.who.int/NR/rdonlyres/BA9EDC4B-278C-4D6E-B78E24BCAFA90AD1/0/201122009_OR_InfluenzaVictoria_AUS1.pdf

16. Lackenby A, Moran Gilad J, Pebody R, Miah S, Calatayud $\mathrm{L}$, Bolotin S, et al. Continued emergence and changing epidemiology of oseltamivir-resistant influenza A(H1N1)2009 virus, United Kingdom, winter 2010/11. Euro Surveill. 2011;16(5):pii=19784. Available from: http://www. eurosurveillance.org/ViewArticle.aspx?Articleld=19784

17. World Health Organization (WHO). Summary of influenza antiviral susceptibility surveillance findings, September 2010 - March 2011. WHO; 6 Jun 2011. Available from: http:// www.who.int/influenza/gisrs_laboratory/updates/antiviral_ susceptibility/en/index.html

18. Meijer A, Lackenby A, Hungnes O, Lina B, van der Werf $\mathrm{S}$, Schweiger B, et al. Oseltamivir-resistant influenza A $\left(\mathrm{H}_{1} \mathrm{~N}_{1}\right)$ virus, Europe, 2007-08 season. Emerg Infect Dis. 2009;15(4):552-60.

19. Opatowski L, Fraser C, Griffin J, de Silva E, Van Kerkhove MD, Lyons EJ, et al. Transmission Characteristics of the $2009 \mathrm{H}_{1} \mathrm{~N}_{1}$ Influenza Pandemic: Comparison of 8 Southern Hemisphere Countries. PLoS Pathog. 2011;7(9):e1002225. 